\title{
Wielowymiarowe poczucie tożsamości społeczno-kulturowej. Idea i badanie. Perspektywa pedagogiczna
}

\begin{abstract}
STRESZCZENIE
Artykuł dotyczy ważnego aspektu tożsamości społeczno-kulturowej, jakim jest autoidentyfikacja jednostki jako członka zbiorowości. Autor podkreśla konieczność łącznego analizowania czterech najważniejszych sfer makrokulturowej identyfikacji: euro_globalnej, narodowej, religijnej i regionalnej. Tekst zamyka metodologiczna propozycja diagnozy profilu identyfikacji społeczno-kulturowej jednostki.
\end{abstract}

\section{Słowa kluczowe:}

edukacja międzykulturowa, tożsamość, autoidentyfikacja społecznokulturowa, profil identyfikacji społeczno-kulturowej

\section{ABSTRACT}

The article concerns an important aspect of the sociocultural identity which is the self-identification of an individual as a member of the community. The author stress es the importance of the profile description of an individual's sociocultural identity. He emphasizes the need of joint analysis of the four most important areas of macrocultural identification: euro_global, national, religious and regional. The text is concluded with a methodological proposal for the diagnosis of an individual's sociocultural identification profile.

${ }^{1}$ Mirosław Sobecki, Wydział Pedagogiki i Psychologii, Uniwersytet w Białymstoku, Polska, m.sobecki@uwb.edu.pl. 


\section{Keywords:}

intercultural education, identity, self-identification, sociocultural identification profile

Kiedy zastanawiamy się nad istotą tożsamości jako cechą człowieka, często dochodzimy do wniosku, że u jej podłoża znajduje się refleksyjność. Stąd już blisko do stwierdzenia, że tożsamość jednostki to refleksyjna świadomość obejmująca jej nacechowane aktywnością relacje z rzeczywistością, w wymiarach przestrzenno-substancjonalnym oraz temporalnym. Tożsamość jednostki - a zwłaszcza tożsamość społeczno-kulturowa - nie jest więc po prostu czymś danym lub zastanym, jest czymś, co musi być sukcesywnie wytwarzane i podtrzymywane przez refleksyjnie działającą jednostkę. Tożsamość człowieka zależy od jego zdolności do podtrzymywania temporalnego wymiaru określonej autonarracji, od zdolności do włączania do swojej biografii bieżących wydarzeń, tworząc z nich nieprzerwaną historię o sobie. Stąd też często przywoływany jest postulat o takie traktowanie tożsamości, w którym analizując teraźniejszość, uwzględniamy dziedzictwo przeszłości, jednocześnie antycypując przyszłość. Syntetycznie wyraził to Charles Taylor (2001, s. 94), pisząc: „aby mieć jakieś wyobrażenie tego, kim jesteśmy, musimy mieć wyobrażenie tego, jak stawaliśmy się i dokąd zmierzamy”.

Według Anthony’ego Giddensa (2010, s. 76) osoba, której tożsamość jest w miarę stała, po pierwsze - ma poczucie ciągłości biograficznej, a więc ,jest w stanie odnieść się refleksyjnie do przebiegu własnego życia i mniej lub bardziej wyczerpująco zrelacjonować je innym”; po drugie - „ma poczucie własnej wartości; ma dość szacunku dla samej siebie”, by zachować poczucie, że „refleksyjnie kontroluje rzeczywistość, a nie jest jedynie jej bezwładnym elementem”; i wreszcie po trzecie - poprzez wczesne relacje zaufania osoba ta „wykształciła kokon ochronny, który w sytuacjach życia codziennego izoluje ją od wpływu czynników, mogących naruszyć integralność tożsamości”.

Wszystkie te trzy aspekty można odnieść do tożsamości społeczno-kulturowej obejmującej wszystkie ważne wymiary zaangażowania jednostki. Kulturowa świadomość biograficzna, umiejętność refleksyjnego odnoszenia się do niej oraz wynikające z niej poczucie wartości tworzy swoistą barierę ochronną ułatwiającą redukcję egzystencjalnych lęków. Jedynie w sytuacji, kiedy radzimy sobie z samymi sobą, możemy wyjść naprzeciw Innemu kulturowo. Tylko wtedy stosunek do kulturowej odmienności ma szanse wyjść poza wąsko rozumianą tolerancję, w której ledwie znosimy osoby, które w swoim kulturowym funkcjonowaniu odbiegają od tego, co znamy z własnych grup odniesienia. W tym miejscu dochodzimy do sedna edukacji międzykulturowej. Mądre otwarcie na odmienność 
noszące znamiona symbiozy kulturowej nie jest możliwe, gdy odczuwamy - tożsamościowe, głęboko egzystencjalne - lęki. W takiej sytuacji otwarcie grozi albo obronnym usztywnieniem, związanym z aktywacją stereotypów, albo konwersją. Z oczywistych względów ani jedno ani drugie nie jest pożądane. Stąd tak ważne są oddziaływania zmierzające do wzmacniania świadomości w zakresie wielowymiarowej tożsamości, które pozwolą uniknąć egzystencjalnych lęków i mądrze korzystać z kulturowego pluralizmu (Sobecki, 2004).

Wspomniany już angielski myśliciel Charles Taylor (1988) wiele lat temu podkreślał, że autointerpretacje są dla każdego z nas tak istotne, gdyż w dużym stopniu stanowią o ostatecznym kształcie naszego życia. Według niego tożsamość można opisywać jako konstelację autointerpretacji, które dotyczą sposobów rozumienia samego siebie. Owe autointerpretacje w sposób szczególny związane są z kulturą. Ten pogląd wpisuje się zdecydowanie w założenie, że tożsamość - w tym tożsamość społeczno-kulturowa - stanowi jedną z najbardziej uniwersalnych ludzkich potrzeb, jaką jest potrzeba przynależności, oraz związane z nią potrzeby bycia akceptowanym i bezpieczeństwa. Bezpośrednio nawiązał do tego Zbigniew Bokszański (2005, s. 17), kiedy analizował egzystencjalny kontekst tożsamości. W opinii autora dotyczy on „uczestników życia społecznego, demonstrujących i komunikujących na różne sposoby „problematyczność” działań i odczuć wiążących się z tożsamością i czyniących ów problem dolegliwym w potoczności”. Właśnie zaistnienie dylematów tożsamościowych w potoczności, a nie w naukowej refleksji, stanowi o istocie egzystencjalnego kontekstu tożsamości, a także o jej fundamentalnie pedagogicznym znaczeniu. Kształtowanie się tożsamości, w tym tożsamości społeczno-kulturowej, staje się bardzo ważnym obszarem praktyki społecznej, w tym nade wszystko - wychowania (Park, 2015).

Brak zdolności do budowania satysfakcjonującej autodefinicji, kłopoty z określeniem punktów odniesienia do tworzenia zbiorowego Ja czy wreszcie brak możliwości osadzania społeczno-kulturowego obrazu siebie w dziedzictwie kulturowym grup odniesienia w decydującym stopniu stanowi o rozterkach współczesnego człowieka, a w szczególności adolescenta. Trzeba w tym miejscu podkreślić, że gęstniejąca rzeczywistość skutkuje demonstrowaniem problematyczności działań i odczuć. Jest to powiązane z wciąż postępującą dyfuzją przestrzeni kulturowych, której efekty stają się zasadniczym podłożem tożsamościowych dylematów.

Oczywiste jest, że na nasze autodefinicje istotny wpływ mają Inni, czyli ci, których lokujemy poza granicami zbiorowości, z którymi się identyfikujemy. Jak zauważył A. Giddens (2010), wśród podstawowych pytań, które sobie stawiamy, obok tych dotyczących istoty istnienia i natury bytu oraz tych, które wynikają z relacji między światem zewnętrznym a życiem ludzkim, są także te, które wynikają 
ze znaczenia, jakie dla naszej egzystencji ma istnienie innych, a intersubiektywność nie wywodzi się z subiektywności; jest wprost przeciwnie, zaś kulturowa subiektywność stanowi głównie efekt interakcji z innymi jednostkami.

\section{PODSTAWOWE WYMIARY SPOKECZNO-KULTUROWEJ IDENTYFIKACJI}

Najbardziej charakterystyczne dla prezentowanego tu podejścia jest używanie pojęcia „poczucie tożsamości społeczno-kulturowej”, które rozumiem jako nieredukowalny, krańcowo subiektywny element struktury Ja. Cechuje je - wyrażający się w deklaracjach jednostki - subiektywizm. Uzasadnienia takiego podejścia należy szukać w samym rdzeniu obecnej w naukach społecznych humanistycznej perspektywy. Już w II połowie XX w. psychologowie zauważyli, że ludzie skłonni są opisywać siebie za pomocą tych kategorii, które są dla nich samych ważne, a schematy Ja tworzone są wokół tych wymiarów Ja, które odróżniają pojedyncze osoby od innych lub odnoszą się do tych dziedzin, w których mogą się z innymi porównywać (Fiske, Pavelchak, 1993, s. 113). W ten sposób jednostki ujawniają całkowicie elementarne odczucia dotyczące ich przynależności grupowej czy raczej przynależności grupowych, które właśnie stanowią poczucie tożsamości.

Poczucie tożsamości nie może być narzucone. Jest ono natomiast efektem dojrzałej autonomii osobowej i podmiotowości oraz jest związane z głębokimi przewartościowaniami w najbardziej elementarnych wymiarach życia. Zwykle poczucie tożsamości jest budowane w oparciu o relacje w najbliższym środowisku i jest mocno powiązane z dziedziczeniem habitusu (Holt, Bowlby, Lea, 2013), W skrajnych sytuacjach może dochodzić jednak do radykalnych zmian w poczuciu tożsamości i konwersji. Trzeba podkreślić, że w obrębie elementarnych praw człowiek może w pełni decydować o swojej przynależności grupowej i nikt z zewnątrz - nawet w imię najbardziej obiektywnych przesłanek - nie może wywierać presji na samookreślenie. Z takim ujęciem wprost koresponduje wypowiedź jednego z holenderskich historyków, który tuż po zakończeniu II wojny światowej, podczas wykładu inauguracyjnego na University College w Londynie w czerwcu 1945 roku tak określał istotę tożsamości narodowej: „Poczucie narodowe istnieje w umysłach ludzi, (...) które są dla niego jedynym sensownym środowiskiem (...) Poza ludzkimi umysłami poczucie narodowe istnieć nie może, ponieważ jest to sposób widzenia samego siebie, a nie odrębny byt an sich. Można je odkryć za pomocą zdrowego rozsądku, a jedyną dyscypliną ludzkiej nauki, która jest w stanie je opisać i zanalizować, jest psychologia (...) Ta świadomość, to poczucie przynależności narodowej, ów narodowy sentyment to coś więcej niż cecha cha- 
rakterystyczna określonego narodu. To sama istota narodowości” (Renier, 1946, s. 16). Julian Tuwim, jedna z najbardziej znanych osób, u których dziedzictwo krwi i społeczno-kulturowa autoidentyfikacja nie były tożsame, pisał ,jestem Polakiem, bo mi się tak podoba” (Tuwim, 2001, s. 444). Wypowiedź poety stanowi najlepszą egzemplifikację istoty poczucia tożsamości, w której subiektywizm jest kwestią fundamentalną i niepodważalną. W podobny sposób interpretował to Jerzy Nikitorowicz, kiedy na samym początku budowania refleksji w obrębie edukacji międzykulturowej w Polsce pisał w sposób następujący: „jestem tym, kim chcę być, a nie tylko tym, jak chcą mnie zaszufladkować inni” (Nikitorowicz, 1995, s. 83).

W refleksji dotyczącej poczucia przynależności grupowej do definiowanych kulturowo zbiorowości możemy wyodrębnić cztery podstawowe kategorie, w obrębie których - z różnym natężeniem - występuje autoidentyfikacja. Po pierwsze jest to kultura w skali kontynentalnej - kultura europejska, po drugie samoopisy dotyczące związku z narodem, po trzecie z religią (tu rozumianą jako przestrzeń kulturowa) i po czwarte wreszcie autoidentyfikacje dotyczące zbiorowości regionalnych czy wręcz lokalnych. Współczesny człowiek w sposób naturalny funkcjonuje w wymienionych wymiarach kulturowych. Nie zawsze jednak sobie to uświadamia i nadaje temu właściwe znaczenie. Antonina Kłoskowska (1996, s. 103) u schyłku XX w. podkreślała, że „uczestnictwo w narodowej wspólnocie nie pochłania i nie wyczerpuje całego człowieka. Jest on ponadto członkiem innych wspólnot, wielu innych zbiorowości, grup celowych i społeczności”. Takie podejście jest silnie akcentowane także we współczesnej edukacji. Pedagodzy zauważają, że „coraz bardziej istotnym staje się równoczesne zakorzenienie w ojczyźnie prywatnej oraz bycie i czucie się członkiem szerszej społeczności narodowej, państwowej (...) europejskiej i światowej” (Nikitorowicz, 2003, s. 44). Niemal identyczne stanowisko reprezentują także wybitni historycy. Przytoczę tu charakterystyczną wypowiedź Henryka Samsonowicza (2002, s. 31): „Człowiek - istota społeczna - dobrze się czuje w ramach wspólnoty: zapewnia mu ona poczucie bezpieczeństwa, zapewnia mu prestiż dający mu psychiczną satysfakcję. (...) Wydaje się, że cechą ludzką jest potrzeba przynależności do mniejszych i większych wspólnot: rodzinnej, lokalnej czy regionalnej, zawodowej, narodowej, państwowej. Oczywiście także do tych najszerszych - do europejskiej, do wspólnoty wiary, wreszcie do gatunku ludzkiego.” 


\section{EUROPEJSKI WYMIAR TOŻSAMOŚCI}

Kształtowanie poczucia przynależności do europejskiej wspólnoty kulturowej stanowi dziś wielkie edukacyjne wyzwanie. U jego podłoża leży pogląd sformułowany niegdyś przez znakomitego znawcę kultury antycznej Stefana Srebrnego (1984, s. 24). Pisał on, że członek każdego z narodów zamieszkujących Europę „jest zarazem członkiem wielkiej rodziny narodów o kulturze europejskiej; obok cech, charakteryzujących go jako Polaka, Francuza, Niemca, posiada on cechy właściwe wszystkim tym narodom, które jednoczy przy wszystkich swych odmianach i różnicach terytorialno-narodowych w gruncie rzeczy jednolita kultura europejska”.

Bardziej w kontekście identyfikacyjnym pisała o europejskim wymiarze tożsamości Jolanta Miluska (2007). Według niej, gdy traktujemy tożsamość społeczną jako sumę wszystkich społecznych identyfikacji, można doprowadzić do wyartykułowania „swojej identyfikacji z grupą ponadnarodową, mającą wspólne korzenie kulturowe i ten sam region zamieszkania, a więc z Europą”. Początek XXI w. stawia przed edukacją nowe wyzwania związane z procesami zachodzącymi w ramach kontynentu. W sytuacji przybierających na sile nacjonalizmów oraz tendencji populistycznych trzeba wspierać rozpoczęte procesy integracji. Coraz wyraźniejsza jest potrzeba skuteczniejszego niż dotychczas akcentowania kulturowej wspólnoty Europejczyków, dookreślania elementów stanowiących wspólny fundament, na którym zbudowano poszczególne kultury narodowe. Dotychczasowe koncentrowanie się w zabiegach kulturalizacyjnych przede wszystkim na narodzie wymaga zmiany proporcji na rzecz dowartościowania perspektywy europejskiej. Dotyczy to przede wszystkim kulturalizacji instytucjonalnej realizowanej w poszczególnych krajach w ramach obowiązkowej edukacji. Trzeba w niej uwzględniać zarówno to, co tkwiło u podłoża formowania się europejskiej cywilizacji, czyli antyk i chrześcijaństwo, jak również wkład, który wnosiły do wspólnego skarbca europejskiej kultury poszczególne wspólnoty nowożytnej Europy.

Chociaż praca w zakresie systematycznego budowania europejskiego wymiaru tożsamości społeczno-kulturowej w zasadzie jest dopiero przed nami, to jednak świadomość bycia członkiem europejskiej wspólnoty kulturowej w różnym stopniu jest już obecna w autodefinicjach mieszkańców kontynentu. Najczęściej wyraża się to w poczuciu bycia członkiem zbiorowości o charakterze politycznym. Taka sytuacja wynika z akcentowania w przestrzeni medialnej politycznych efektów integracji europejskiej. Stąd dzisiaj dla wielu osób bycie Europejczykiem jest jednoznaczne z byciem „obywatelem” Unii Europejskiej. 


\section{WSPÓLNOTA NARODOWA W WIELOWARSTWOWEJ I WIELOWYMIAROWEJ TOŻSAMOŚCI}

Naród w świadomości przeciętnego człowieka jest zbiorowością naturalną, istniejącą od niepamiętnych czasów. Jednak w takim kształcie, jak obecnie, istnieje relatywnie od niedawna. Złudzenie starożytności i naturalności narodu jest efektem utrwalenia w ideologiach narodowych nastawień, które towarzyszą ludzkości od zarania jej istnienia. Są one związane z podziałem świata na swoich i obcych i odwołują się do wzorów, symboli i faktów historycznych z bardzo odległej przeszłości, będących punktem odniesienia do budowania tożsamości zbiorowej.

Identyfikacja narodowa jest jednym z elementarnych wymiarów opisu w analizowaniu tożsamości społecznej. Dzisiaj najczęściej mówimy o narodzie jako zbiorowości politycznej lub zbiorowości opartej na dziedzictwie kultury duchowej. Pierwsze ujęcie ukształtowane zostało ostatecznie w czasie Rewolucji Francuskiej u schyłku XVIII w. Rozpoczął się czas obywateli, tworzących w ustroju republikańskim nowe oblicze narodu. Wszelkie odmienności, a zwłaszcza kulturowe, nie mogły odtąd uprzywilejowywać jednych wobec drugich. W ten sposób zaakcentowano, że naród definiowany politycznie konstytuowany jest tylko i wyłącznie przez respektujące fundamentalne wartości jednostki - obywateli (Schnapper, 1994, s. 350).

Drugi sposób rozumienia narodu jako wspólnoty ducha pojawił się na dobre w Niemczech w okresie Romantyzmu. Zgodnie z nim narodową zbiorowość tworzy wspólnota przeżyć zbudowanych wokół wytworów kulturowych charakterystycznych dla określonej zbiorowości. W tej perspektywie wyraźnie podkreśla się wielość i różnorodność narodowych kultur. Prekursorem takiego sposobu myślenia o narodzie był Johann G. Herder. Uznawał on kulturowy pluralizm za wartość samą w sobie. Konsekwencją takiego stanowiska było definiowanie narodu przez samookreślenie kulturowe jego członków, związane z unikalnym i - co ważne - nierywalizacyjnym wobec innych zbiorowości zespołem zwyczajów i styl życia. W tym ujęciu naród rodził się z rezonansu serc, skupiał się wokół wybitnych jednostek, zwłaszcza pisarzy i artystów, oraz ich wytworów.

Jednym z pierwszych myślicieli, którzy wskazali na dwojakie rozumienie narodu był niemiecki historyk Friedrich Meinecke, który zaproponował „rozróżnienie narodu państwowego i narodu kulturalnego w zależności od tego, czy wspólnota, która uważała się za narodową, tworzyła jedność z państwem, czy też była określana przede wszystkim przez więzi językowe i kulturalne” (Hroch, 2003, s. 98). Owe dwie wizje narodu wymagają jednak od człowieka jako członka narodowej zbiorowości innego rodzaju zachowań. Gdy naród polityczny żąda od 
obywatela subordynacji i przestrzegania elementarnych praw, naród kulturowy wymaga przede wszystkim zaangażowania. Osoby tworzące go wiąże nadawanie znaczenia dziedzictwu kulturowemu przodków i wola jego podtrzymywania. To właśnie w tym przypadku - w sposób szczególny - można mówić o związku teraźniejszości z przeszłością i z antycypowaną przyszłością. O ile wspólnota obywatelska ma charakter raczej synchroniczny, to w zbiorowości opartej na kulturze silniejszy jest kontekst diachroniczny. Ta konstatacja ma bardzo duże znaczenie dla wychowania. Wydarzenia polityczne i społeczne zachodzące w ostatnim czasie w naszej części kontynentu wyraźnie wskazują, że odkładanie narodu jako kategorii identyfikacyjnej do lamusa historii jest zdecydowanie przedwczesne. Z tego względu udział szkoły w integracji narodowej nie jest tylko przejawem swoistej cechy tej instytucji, jaką niewątpliwie jest inercja, ale kwestia narodowa wciąż pozostaje ważnym polem realizacji przez tę instytucję funkcji socjalizacyjnej (kulturalizacyjnej).

Warto jednak zauważyć za A. Kłoskowską (1996), że niewłaściwe jest ograniczanie się do analiz tożsamości jednostki tylko w zakresie tożsamości narodowej. Natomiast można i należy pytać o miejsce, rolę i funkcje narodowej identyfikacji i przyswojenia kultury w całej, totalnej tożsamości człowieka. Nie podzielając bardzo rygorystycznego podejścia autorki do stosowania terminu „tożsamość” w pełni zgadzam się co do roli sfery narodowej w całościowo pojmowanej, wewnętrznie złożonej tożsamości. We współczesnym świecie zagadnienie wewnętrznej heterogeniczności jest bardzo istotne i zasługuje na samoistne zainteresowanie.

Ważną kwestią są relacje między ideą narodu a ideą integracji międzykulturowej. Analizy tego typu pojawiają się zwłaszcza wśród osób osadzonych w realiach społeczno-kulturowych dosyć odległych od tego, co ma miejsce w środkowej i wschodniej części Europy. Zwykle są one wyprowadzane z dominującej na zachodzie kontynentu politycznej wizji wspólnoty narodowej, podczas gdy we wschodniej części wyraźną przewagę ma koncepcja kulturowa. W moi przekonaniu integracja międzykulturowa absolutnie nie wyklucza nadawania znaczenia wspólnocie narodowej. Wręcz przeciwnie, wydaje się, że obydwie perspektywy są równie ważne, dopóki istnieją państwa narodowe. Integracja międzykulturowa rozumiana jako przeciwstawna wspólnocie narodowej w istocie skazuje się na samounicestwienie. Tylko traktowane komplementarnie obydwie sfery mogą stanowić przestrzeń skutecznych i pożądanych działań edukacyjnych. 


\section{MIEJSCE REGIONU W BUDOWANIU KULTUROWYCH AUTOIDENTYFIKACJI}

Po drugiej wojnie światowej wiele uczyniono, aby ze świadomości Polaków wyrugować związek z regionem i małą ojczyzną. W Polsce powojennej - zapewne w celu zatarcia w świadomości ludzi istoty jagiellońskiej Rzeczypospolitej składającej się z Korony i Litwy - celowo unikano kontekstów regionalnych. Był to bezpośredni efekt pojałtańskiej zmiany granic i czystek etnicznych. Mimo zmian politycznych i cywilizacyjnych w wielu krajach nadal można wyróżnić szereg regionów posiadających wyraźną historyczno-kulturową specyfikę. Polskie Podhale, francuska Prowansja czy niemiecka Bawaria są przykładami na istnienie wyraźnych mutacji w obrębie współczesnych kultur narodowych. Ale kategoria regionu powinna być uwzględniana w wychowaniu nie tylko w tak ewidentnych przypadkach. Terytorialna specyfika, wynikające z niej poczucie swojskości może i powinno stanowić istotny element w socjalizacji. Warto zauważyć za S. Ossowskim (1984), że „na niektórych pograniczach o skomplikowanej historii bywa wszakże i tak, że mieszkańcy nie sięgają poza więź regionalną, nie posiadają, jak się mówiło, poczucia narodowego”. Choć taka opinia może być dyskusyjna w konkretnych przypadkach, to jednak trudno podważyć stwierdzenie, że przywiązanie do regionu i kultury, w niektórych przypadkach, ma priorytetowe znaczenie w sytuacji tożsamościowej autoidentyfikacji. Taką opinię wyraził Józef Kozielecki (1997, s. 190), wskazując, że kultura regionalna - najbliższa - zakorzeniona w małej ojczyźnie odgrywa prawdopodobnie najważniejszą rolę w rozwoju osobowości jednostek.

Region jest źródłem tego, co w tożsamości kulturowej człowieka jest mu najbliższe, co stanowi element codziennych interakcji. Dla przedstawienia tej sfery doświadczeń Katarzyna Dadak-Kozicka (1999) użyła stosunkowo rzadkiego terminu „rodzimość”. Według niej rodzimość reprezentuje sobą określony kod, który przyswajany jest jako pierwszy, zanim człowiek pozna inne kody, kultury i ich symbole. Tak dzieje się z małym dzieckiem kształtującym się w konkretnej rodzinie oraz konkretnym środowisku lokalnym. Przywoływana autorka pisze: „rodzimość ma swój rodowód etniczny i regionalny, a krajobrazy i zwyczaje regionalne stają się dla dorastającego dziecka podstawowym środowiskiem, w którym następują inicjacje kulturowe”. Należy jednak dostrzec niebezpieczeństwo, na które wskazuje A. Kłoskowska (1996, s. 111) kiedy pisze, że: „ograniczenie poczucia związku z kulturą narodową do małej ojczyzny jest oznaką peryferyjnej świadomości narodowej”. Nazbyt wyeksponowana sfera regionalna w tożsamości kulturowej może skazywać człowieka na funkcjonowanie na marginesie innych ważnych 
grup odniesienia. Dlatego jest tak ważne, aby poszczególne sfery tożsamości społeczno-kulturowej - także ta regionalna - były postrzegane jako wzajemnie się uzupełniające, a nie konkurencyjne wobec siebie czy wręcz wypierające jedna drugą.

\section{RELIGIA JAKO PRZESTRZEŃ KULTUROWA W WIELOWYMIAROWEJ TOŻSAMOŚCI}

Sfera religijna stanowi kolejną, niezwykle ważną przestrzeń tożsamościowych autodefinicji. Nadawanie jej znaczenia - jako sferze kulturowej - jest niezwykle istotne w edukacji choćby w kontekście przybierającej na sile konfrontacji cywilizacji islamu i chrześcijaństwa. Co prawda w owej konfrontacji częstokroć religia jest wykorzystywana instrumentalnie - tak przez jedną, jak i drugą stronę - to jednak nikt nie zaprzeczy, że samo (auto)definiowanie się ludzi w sferze religijnej stanowi współcześnie ważny kontekst komunikowania się przedstawicieli różnych religii, prezentowania wzajemnych stanowisk i interpretowania zachowań.

W analizach tożsamości społeczno-kulturowej często zwraca się uwagę na to, że religia i etniczność mają wiele punktów stycznych, chociaż relacje między tymi kategoriami nie są jednoznaczne. Religia pełni istotne funkcje kulturowo-integracyjne w sytuacji zbiorowości pozbawionych własnej państwowości. Wówczas granice religijne stają się często granicami lokalnych kultur i prywatnych ojczyzn (Babiński, 1999, s. 200). Halina Rusek skonstatowała, że w XIX w. na terenach byłej Rzeczypospolitej Kościół katolicki pełnił przede wszystkim funkcję pogłębiania świadomości w sferze odczuwania odrębności przez zbiorowości społeczne (Rusek, 2002). Związane to było z jednej strony z sytuacją polityczną (brakiem niepodległości) oraz silnym zróżnicowaniem religijnym (zwłaszcza opozycją propaństwowej Cerkwi prawosławnej i popierającego „buntowników” Kościoła katolickiego), przy czym kwestia związków religii z tożsamością nie dotyczy jedynie tożsamości narodowej. W związku z dyskusją dotyczącą kształtu konstytucji europejskiej na pierwszych stronach gazet znalazła się kwestia znaczenia chrześcijaństwa dla tożsamości europejskiej. Mimo kontrowersji związanych z filozoficzną stroną zagadnienia i kontestacji ze strony środowisk laickich nikt nie kwestionuje roli kultury chrześcijańskiej w formowaniu się europejskiej tożsamości kulturowej.

Można jednak odnieść wrażenie, że obecnie w naukach społecznych na rolę religii w kształtowaniu podstaw tożsamości społecznej, w odróżnieniu od etniczności, zwraca się uwagę znacznie rzadziej. Nie dotyczy to niektórych regionów 
Europy, takich jak na przykład Irlandia czy Bałkany. Można wskazać także przykłady, w których religia jest głównym wyróżnikiem grupy. Poza judaizmem, który jest głównym kryterium tożsamości żydowskiej, przykłady te dotyczą zbiorowości zamieszkujących obszary poza Europą. Takie grupy pozbawione wyznania nie są w stanie znaleźć żadnego innego kryterium, które może stanowić o ich tożsamości. Przykładem są choćby Chaldejczycy, Maronici i Samarytanie, którzy odróżniają się od innych Arabów przede wszystkim tym, że są chrześcijanami.

Zaprezentowane wyżej obszary identyfikacji społeczno-kulturowej, stanowią ważne punkty odniesienia w budowaniu tożsamości mieszkańców Europy Środkowo-Wschodniej. Najczęściej są one analizowane oddzielnie. Tymczasem każda osoba, choć w różnym stopniu, postrzega siebie jako członka wielu zbiorowości. Wśród tychże zbiorowości są także te przedstawione wyżej. Rzecz w tym, aby postrzegać je łącznie, uwzględniając wzajemne relacje. Wyłączanie do analiz tylko jednego wymiaru tożsamości wypacza obraz. W istocie ważne jest to właśnie, w jakich relacjach względem siebie znajdują się lojalności jednostki wobec poszczególnych zbiorowości, do których się ona zalicza. Jak się wydaje, kwestia ta ma szczególne znaczenie dla pedagogiki, choćby w kontekście kształtowania poczucia wewnętrznej heterogeniczności kulturowej.

\section{METODOLOGICZNY KONTEKST DIAGNOZOWANIA WIELOWYMIAROWEJ TOŻSAMOŚCI. IDEA PROFILU IDENTYFIKACJI SPOŁECZNO-KULTUROWEJ}

Zbudowana na przytoczonych wcześniej założeniach koncepcja profilu identyfikacji społeczno-kulturowej polega na łącznym ukazywaniu najważniejszych sfer makroidentyfikacyjnych: regionalnej, narodowej, europejskiej i religijnej. W pedagogice taki sposób interpretowania tożsamości kulturowej najwcześniej zaproponowała Irena Wojnar (2000, s. 103), kiedy wskazywała na potrzebę patrzenia na zaangażowanie społeczno-kulturowe człowieka z perspektywy zbiorowości regionalnej, narodowej i europejskiej. Warto przy tym zwrócić szczególną uwagę na sferę europejską w deklaracjach identyfikacji społeczno-kulturowej współczesnych Polaków. Mimo że europejska tożsamość kulturowa w kontekście edukacyjnym wciąż jest raczej zadaniem niż efektem, jestem przekonany, że tym bardziej należy uwzględniać wymiar europejski we wszelkiego rodzaju analizach tożsamościowych.

Człowiek w trakcie życia nabywa zdolności do integracji różnego rodzaju identyfikacji. Trzeba przyznać, że właśnie takie zintegrowane identyfikacje niezbyt często stanowią przedmiot zainteresowania przedstawicieli nauk społecznych. 
W badaniach nader często każdą z identyfikacji analizuje się oddzielnie. W sytuacji niezwykłej wręcz intensyfikacji aktów komunikacyjnych jednostek jako reprezentantów różnych zbiorowości, którego obecnie doświadczamy, wydaje się być wyjątkowo anachroniczne.

Każdy człowiek z różną intensywnością wyobraża siebie jako członka określonych zbiorowości kulturowych. Dotyczy to także wyróżnionych czterech typów zbiorowości. Absolutnie elementarnym założeniem jest to, że poczucie przyn ależności do jednego typu zbiorowości nie wyklucza ani nie ogranicza odczuwania związku z inną. To, że zdecydowanie czuję się Polakiem wcale nie oznacza, że nie mogę równie stanowczo opisywać się jako Europejczyk. Silne przywiązanie do religii często współwystępuje z wyrazistą identyfikacją narodową, ale przecież nie determinuje jej i możliwa jest sytuacja, gdy deklarowanemu silnemu związkowi z polskością towarzyszy słabe poczucie związku ze zbiorowością religijną. Przywiązanie do ziemi, którą przez dziesięciolecia lub stulecia zamieszkiwali nasi bezpośredni przodkowie, często stanowiąc wyraziście oryginalną kulturową zbiorowość w wymiarze regionalnym, nie musi w żadnym stopniu umniejszać identyfikacji z polskością. W tym kontekście deklarowany związek z polskością nie wyklucza deklaracji przynależności do zbiorowości Kaszubów lub Ślązaków. Podstawową ideą, która legła u podstaw wyodrębnienia koncepcji profili identyfikacji społeczno-kulturowej były więc wzajemne relacje między czterema wyodrębnionymi wymiarami identyfikacji. Elementarnym kryterium opisującym te relacje jest występowanie bądź niewystępowanie dominacji jednego lub dwu wymiarów nad pozostałymi. Przyjmując takie założenie, możemy teoretycznie założyć następujące sytuacje:

a) niewystępowanie dominacji jakiegokolwiek wymiaru (profil wyrównany)

b) dominację jednego wymiaru (profile jednodominantowe)

c) jednakowo silną dominację dwu wymiarów (profile dwudominantowe)

d) wycofanie jednego z czterech wymiarów, przy równej sile trzech pozostałych (profile z wycofanq jednq ze sfer).

Do diagnozowania profilu identyfikacji społeczno-kulturowej stosujemy bardzo proste narzędzie, którego celem jest uzyskanie deklaracji badanych dotyczących siły ich poczucia związku z wyodrębnionymi zbiorowościami. Przybiera ono następującą postać:

Przyjmujq̨c założenie, że ludzie tworzq różne zbiorowości oparte na wspólnocie kulturowej zaznacz w jakim stopniu czujesz się:

W swoich deklaracjach posługuj się następujq̨cq skalq:

- 2 - zdecydowanie nie czuję się zwiq̨zany z tq zbiorowościq 
- 1 - raczej nie czuję się zwiq̨zany z tq zbiorowościq

0 - trudno powiedzieć (nie mam wyrobionego zdania)

1 - raczej czuję się zwiq̨zany z tq zbiorowościq

2 - zdecydowanie czuję się zwiq̨zany z tq zbiorowościq

a) członkiem kultury ogólnoludzkiej

$-2-10012$

b) Europejczykiem

$-2-10012$

c) Polakiem

$-2-10012$

d) członkiem innej zbiorowości narodowej

$-2-1012$

e) członkiem zbiorowości lokalnej (swojej wsi, swego miasta)-2 -1 012

f) członkiem zbiorowości regionalnej (tej części kraju, w której mieszkasz)

g) chrześcijaninem

h) członkiem innej zbiorowości religijnej

$-2-10012$

i) katolikiem

$-2-10012$

j) członkiem innej zbiorowości wyznaniowej

Tak skonstruowane narzędzie pozwala badać grupowe natężenie identyfikacji społeczno-kulturowej we wszystkich wyodrębnionych kategoriach, jak też wyodrębnić profile identyfikacji społeczno-kulturowej poszczególnych badanych osób. W celu wyodrębnienia profili wstępnie ustala się najwyższe natężenie identyfikacji odpowiednio w kategoriach:

A: a) i b) - stanowiących o euro_globalnym wymiarze identyfikacji;

B: c) i d) - stanowiących o narodowym wymiarze identyfikacji;

C: e) i f) - stanowiących o regionalnym wymiarze identyfikacji;

D: g), h), i) oraz j) - stanowiących o religijnym wymiarze identyfikacji.

W rezultacie takiej operacji otrzymujemy cztery wartości tworzące zgeneralizowany profil. Porównanie tych wartości doprowadza do ustalenia dominanty w każdym profilu. W rezultacie można wyróżnić 15 teoretycznych typów profili, które zostaną niżej skrótowo zaprezentowane.

Pierwsza sytuacja obejmuje takie przypadki, w których osoba z równą siłą wyraża swoje przywiązanie do każdej przestrzeni identyfikacyjnej. Taki profil został nazwany profilem wyrównanym. Został on zaprezentowany poniżej w formie graficznej.

Jak widzimy identyfikacje we wszystkich analizowanych sferach mając jednakową wartość, tworząc prostą równoległą do osi odciętych. Najczęściej spotykamy się z sytuacją, kiedy we wszystkich wymiarach wskazywane są najwyższe punkty skali (w przypadku zastosowanej skali - „zdecydowanie czuję się”), ale zdarzają 


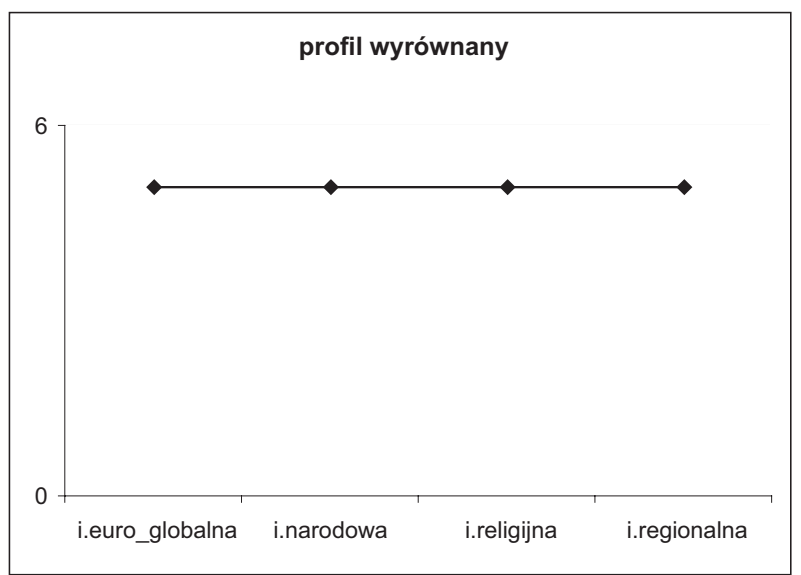

Ryc. 1. Natężenie identyfikacji społeczno-kulturowej w profilu wyrównanym

się też sytuacje, kiedy badany wybiera we wszystkich przypadkach odpowiedź wskazującą na słabszą identyfikację (,raczej czuję się”). Zarówno w jednym, jak i w drugim przypadku mamy do czynienia z profilem wyrównanym. Teoretycznie możliwe są równie silne identyfikacje także na niższych poziomach skali.

Inaczej jest w drugiej z wyróżnionych wcześniej sytuacji, kiedy jeden z analizowanych wymiarów identyfikacyjnych jest wyraźnie silniej eksponowany niż pozostałe. Ponieważ uwzględniono cztery wymiary, to możliwe są także cztery typy profili - odpowiednio z dominantą każdego z wymiarów:

- narodowy (dominacja samookreślenia na skalach Polak lub członek innej zbiorowości narodowej);

- religijny (dominacja samookreślenia na skalach chrześcijanin, reprezentant innej religii, katolik, reprezentant innego wyznania);

- regionalny (najwyższa ranga na skalach identyfikacji z regionem lub miejscowością);

- euro_globalny (najwyższe wartości rang przy określaniu się Europejczykiem lub obywatelem świata).

Najczęściej występują profile z dominantą wymiaru narodowego lub wymiaru religijnego, stąd uwzględniono je w przykładowych reprezentacjach graficznych. Należy zwrócić uwagę, że wartości rang w pozostałych - poza dominującą kategoriach identyfikacyjnych mogą przybierać różne wartości. Warunek jest tylko jeden - każda z nich musi być mniejsza od wartości rangi w kategorii dominującej. 
a)

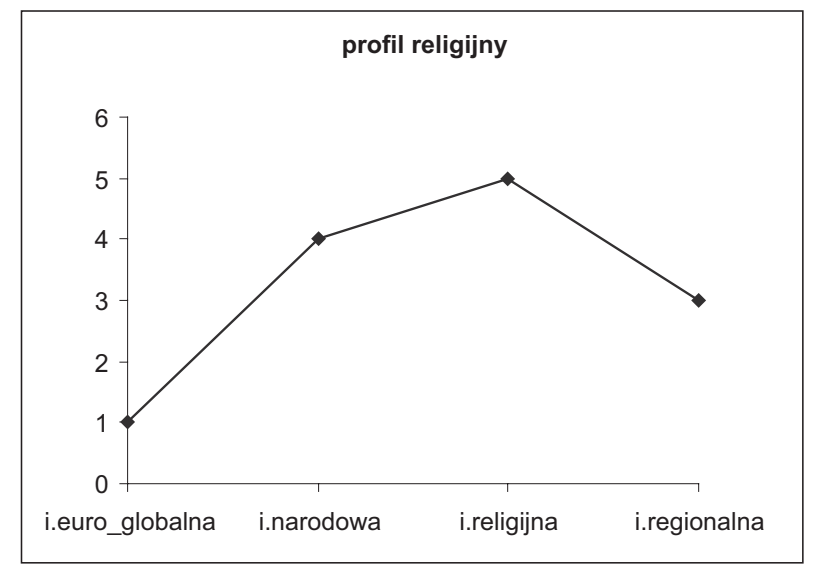

b)

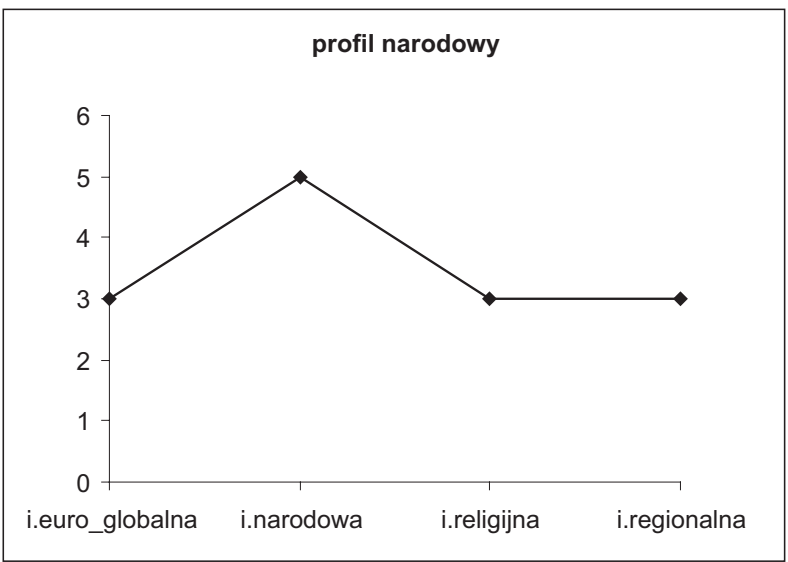

Ryc. 2. Przykłady profili z dominantą identyfikacji religijnej (a) oraz narodowej (b)

Inaczej mówiąc, ważne jest, aby siła identyfikacji w pozostałych wymiarach była mniejsza od deklaracji dotyczącej wymiaru dominującego. Profil narodowy obejmuje te osoby, które najwyżej cenią sobie przynależność do grupy narodowej. Tego typu profil jest charakterystyczny dla syndromu nacjonalistycznego. Jednak może on dotyczyć także etnocentryzmu pozytywnego, czyli patriotyzmu. Czynnikiem różnicującym są tu postawy wobec odmienności kulturowej. Z kolei w profilu religijnym eksponowana jest identyfikacja o charakterze konfesyjnym. Dotyczy ona zwykle osób silnie zaangażowanych w życie społeczności wyznaniowej i mniej przywiązanych do zbiorowości regionalnej, narodowej czy europejskiej. 
Kolejne profile związane są z podwójnq dominantq. Obejmują one sytuacje, w których osoba wyraźnie preferuje dwie przestrzenie identyfikacyjne, każdą z nich taktując w jednakowy sposób. Wyraża się to w identycznych deklaracjach dotyczących poczucia tożsamości w dwu wyodrębnionych przestrzeniach identyfikacyjnych. Teoretycznie możliwe są tu następujące typy profili:

- narodowo-religijny (albo z wycofaną sferą regionalną i euroglobalną);

- narodowo-regionalny (albo z wycofaną sferą religijną i euro_globalną);

- narodowo-euro_globalny (albo z wycofaną sferą religijną i regionalną);

- religijno-regionalny (albo z wycofaną sferą narodową i euro_globalną);

- religijno-euro_globalny (albo z wycofaną sferą narodową i regionalną);

- regionalno-euro_globalny (albo z wycofaną sferą narodową i religijną).

W profilach dwudominantowych możliwości interpretacyjne są bodaj najbogatsze. Oczywiście największe zainteresowanie budzi profil narodowo-religijny, który odpowiada wyjątkowo silnie utrwalonemu niegdyś stereotypowi „Polak - katolik”. Jednak trzeba tutaj koniecznie podkreślić, że profil ten w równym stopniu świadczy o przykładaniu mniejszej wagi do pozostałych dwu wymiarów.

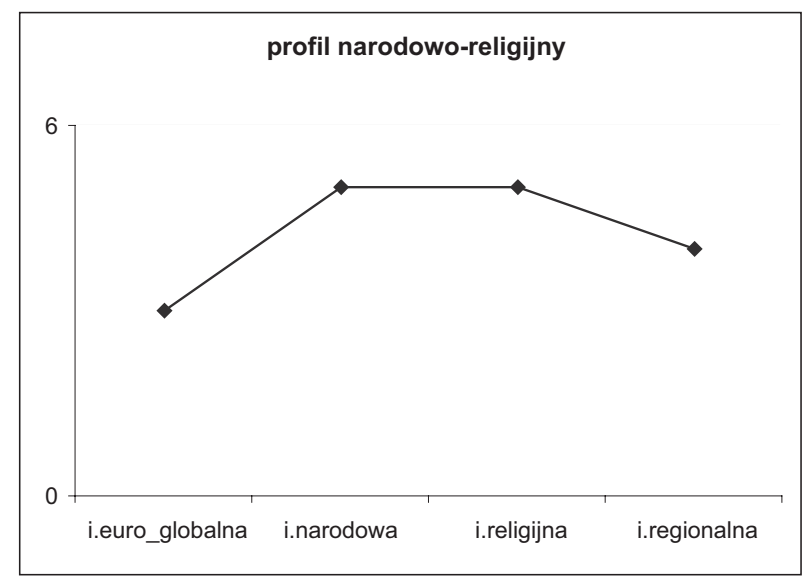

Ryc. 3. Przykład profilu dwudominantowego - profil narodowo-religijny

Bardzo znamienny jest inny profil - religijno-regionalny. Świadczy on o mniejszym znaczeniu nadawanym związkom z narodem i przestrzenią ponadnarodową. Taki profil może charakteryzować osoby skupione na tradycyjnych wartościach, silnie osadzone w lokalnych realiach. Wydaje się, że odzwierciedla on sytuację, kiedy społeczność jest zasadniczo zamknięta i komunikuje się w obrębie własnego, lokalnie wykreowanego uniwersum symbolicznego, ukształtowanego przez historię 
i nie odwołującego się do symboliki tworzącej szersze ponadlokalne wspólnoty. Profil ten jest odpowiednikiem częstego we wschodniej części II Rzeczypospolitej syndromu tożsamościowego znanego pod nazwą tutejszości.

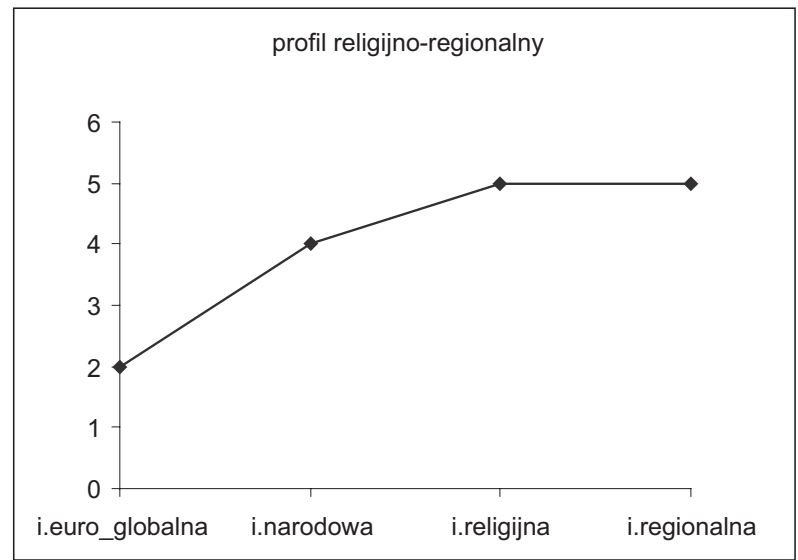

Ryc. 4. Graficzny przykład profilu dwudominantowego - profil religijno-regionalny

I wreszcie ostatnia sytuacja, w której wyłączony zostaje tylko jeden wymiar. Do takich profili zaliczamy:

- profil z wycofaną sferą narodową;

- profil z wycofaną sferą religijną;

- profil z wycofaną sferą regionalną;

- profil z wycofaną sferą euro_globalną.

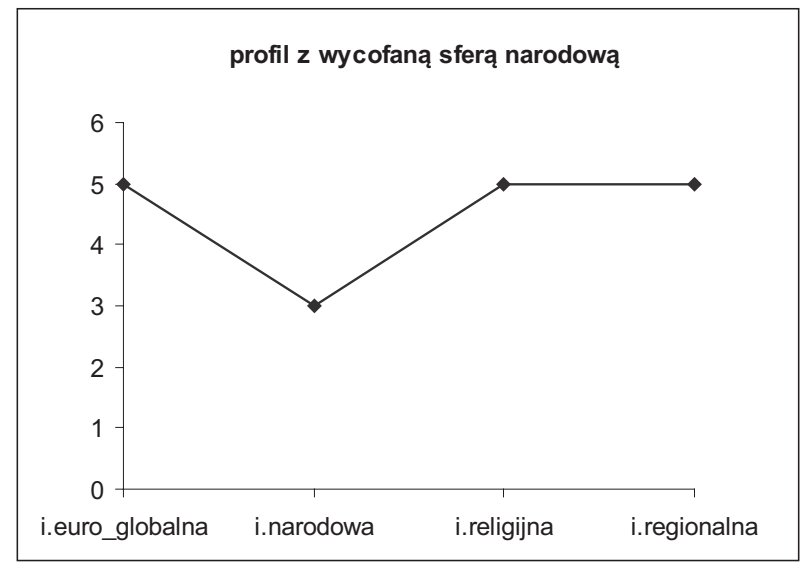

Ryc. 5. Profil z wycofaną sferą narodową 
Najbardziej spektakularny wydaje się profil z wycofanym komponentem narodowym. Może on charakteryzować osoby z wyraźnymi dylematami w sferze identyfikacji narodowej, na przykład pochodzące z rodzin mieszanych narodowościowo. Może być także efektem traumatycznych przeżyć związanych ze stygmatyzacją w wymiarze narodowym. Dotyczy to na przykład osób, które czując się Polakami, zamieszkiwały tereny byłego Związku Radzieckiego, następnie przyjeżdżały do Polski (np. na studia) i tu spotykały się z etykietą „,ruski”.

Wyodrębnionych 15 profili identyfikacji społeczno-kulturowej w usystematyzowany sposób oddaje spektrum identyfikacyjne jednostek z uwzględnieniem wyodrębnionych wcześniej kategorii. Szczególnie ważne jest to w przypadku mieszkańców pogranicza kulturowego, którzy na co dzień najbardziej intensywnie doświadczają procesów dyfuzji kulturowej wpływających na kształtowanie ich tożsamości. Diagnozowanie tych profili wraz z rozpoznawaniem kompetencji do komunikacji kulturowej może stanowić znaczący aspekt w kreowaniu i realizacji polityki oświatowej. Może być też przydatne w samej praktyce edukacyjnej w środowiskach mniejszościowych. W szczególny sposób dotyczy to obszarów intensywnej dyfuzji kultur narodowych w Europie Środkowo-Wschodniej.

\section{Bibliografia}

Babiński, G. (1999). Religia i tożsamość narodowa-zmieniajq̨ce się relacje. W: M. Kępny, G. Woroniecka (red.), Religia i kultura w globalizujq̨cym się świecie. Kraków: Zakład Wydawniczy NOMOS.

Bokszański, Z. (2005). Tożsamości zbiorowe. Warszawa: PWN.

Dadak-Kozicka, K. (1999). Poczucie rodzimości jako fundament uniwersalizmu w sztuce. W: A. Tyszka (red.), Od rodzimości do uniwersalizmu i vice versa. Warszawa.

Fiske, S.T., Pavelchak, M.A. (1993). Reakcje afektywne oparte na przetwarzaniu kategorialnym a reakcje afektywne oparte na przetwarzaniu analitycznym. Rozwinięcie w terminach koncepcji schematów wyzwalających afekt. W: T. Maruszewski (red.), Poznanie, Afekt, Zachowanie. Warszawa: PWN.

Giddens, A. (2010). Nowoczesność i tożsamość. „Ja” i społeczeństwo w epoce późnej nowoczesności. Warszawa: PWN.

Holt, L., Bowlby, S., Lea, J. (2013). Emotions and the habitus: Young people with socio-emotional differences (re)producing social, emotional and cultural capital in family and leisure space-times. W: Emotion, Space and Society, 9.

Hroch, M. (2003). Małe narody Europy. Wrocław: Ossolineum.

Kłoskowska, A. (1996). Kultury narodowe u korzeni. Warszawa: PWN.

Kozielecki, J. (1997). Transgresja i kultura. Warszawa: Wydawnictwo Akademickie „Żak”. Miluska, J. (2007). Tożsamość Europejczyka - fakt czy artefakt? W: J. Nikitorowicz, 
D. Misiejuk, M. Sobecki (red.), Etniczność i obywatelskość w nowej Europie. Konteksty edukacji międzykulturowej. Białystok: Trans Humana.

Nikitorowicz, J. (1995). Pogranicze. Tożsamość. Edukacja międzykulturowa. Białystok: Trans Humana.

Nikitorowicz, J. (2003). Wartości etnosu jako podstawa kształtowania tożsamości wielokulturowej, podłoże konfliktów kulturowych i cel edukacji międzykulturowej. W: T. Lewowicki, E. Ogrodzka-Mazur, A. Gajdzica (red.), Świat wartości i edukacja międzykulturowa. Cieszyn-Warszawa: Uniwersytet Śląski, Filia w Cieszynie - WSP ZNP w Warszawie.

Ossowski, S. (1984). O ojczyźnie i narodzie. Warszawa: PWN.

Park, H. (2015). Learning Identity: a Sociocultural Perspective. Adult Education Research Conference. http://newprairiepress.org/aerc/2015/papers/41, The Pennsylvania State University.

Renier, G.J. (1946). The Criterion of Dutch Nationhood. London: George Allen and Unwin, Ltd.

Rusek, H. (2002). Religia i tożsamość pogranicza. Raport z badań. W: T. Lewowicki, A. Różańska, U. Klajmon (red.), Kwestie wyznaniowe w społecznościach wielokulturowych, Cieszyn: Uniwersytet śląski, Filia w Cieszynie.

Samsonowicz, H. (2002). Członek rodziny czy niechciane dziecko? Wartości wnoszone do dziedzictwa europejskiego przez kraje Europy Środkowej. W: J. Purchla (red.), Europa Środkowa - nowy wymiar dziedzictwa. Kraków: Wydawnictwo Uniwersytetu Jagiellońskiego.

Schnapper, D. (1994). La Communauté des citoyens: Sur l’idée moderne de nation. Paris: Gallimard.

Sobecki, M. (2004). Wielowymiarowa tożsamość kulturowa a egzystencja człowieka w kontekście edukacji międzykulturowej. W: A. Paszko (red.), Edukacja międzykulturowa w Polsce na przełomie XX i XXI wieku. Kraków: WBP.

Srebrny, S. (1984). Teatr grecki i polski. Warszawa: PWN.

Taylor, Ch. (1988). Humanizm i nowoczesna tożsamość. W: Człowiek w nauce współczesnej: Rozmowy w Castelgandolfo 1983. Paris: Editions du Dialogue.

Taylor, Ch. (2001). Źródła podmiotowości. Narodziny tożsamości nowoczesnej. Warszawa: PWN.

Tuwim, J. (2001). My, Żydzi polscy. W: A.K. Kunert (red.), Polacy - Żydzi / Polen - Juden / Poles - Jews 1939-1945. Warszawa: Oficyna Wydawnicza RYTM.

Wojnar, I. (2000). Trzy tożsamości - jedno porozumienie. W: I. Wojnar, Humanistyczne intencje edukacji. Warszawa: Żak. 